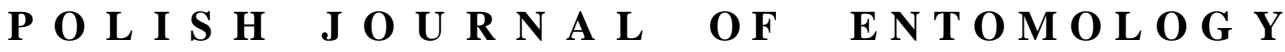

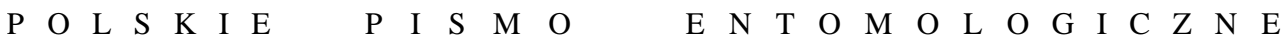

VOL. 84: 85-99

Lublin

30 June 2015

DOI: $10.1515 /$ pjen-2015-0008

\section{Descriptions of new taxa in Otiorhynchus GERMAR, 1822 (Coleoptera: Curculionidae: Entiminae: Otiorhynchini)}

\author{
PIOTR Z. BIAŁOOKI
}

State Plant Health and Seed Inspection, Gdańsk, Na Stoku 48, 80-874 Gdańsk, Poland, e-mail: og-gdynia@piorin.gov.pl; pbialooki@poczta.onet.pl

\begin{abstract}
A new subgenus Podorhynchus subgen. n. (type species Otiorhynchus cylindricus STIERLIN, 1877) of the genus Otiorhynchus, until now confused with Podonebistus ReITTER, 1912, is described. Otiorhynchus (Podonebistus) trichopterus sp. n. from Crete, Otiorhynchus granicus sp. n. from Turkey and $O$. idhaeus sp. n. from Crete (both species in the subgenus Choilisanus REITTER, 1912) are described. Otiorhynchus cylindricus STIERLIN, 1877, O. fortiscapus ARNOLDI, 1972, O. glolae ARNOLDI, 1972, O. korotyaevi DAVIDIAN \& GÜLTEKIN, 2006, and O. ritsae ARNOLDI, 1972, all currently placed in the subgenus Podonebistus are transferred to the newly erected subgenus Podorhynchus.

KEY WORDS: Curculionidae, Entiminae, Otiorhynchini, new subgenus, new species, Crete, Turkey.
\end{abstract}

\section{INTRODUCTION}

A new subgenus of the genus Otiorhynchus GERMAR, 1822 is proposed. Although this genus is divided into more than 100 subgenera, and it would be highly desirable to reduce, not increase the number of its subordinate units, it is still necessary to establish further new subgenera (DAVIDIAN \& SAVITSKY 2006; ALONSO-ZARAZAGA 2013 in MAGNANO \& AlONSO-ZARAZAGA 2013). Furthermore, three new species from the eastern Mediterranean region are described - one placed in the subgenus Podonebistus REITTER, 1912 and the other two in the subgenus Choilisanus REITTER, 1912. The latter group is well represented in the eastern Mediterranean; two new species have recently been described from westernmost Turkey (DAVIDIAN \& KESKIN 2010; DAVIDIAN \& GÜLTEKIN 2015). 


\section{MATERIALS AND METHODS}

The body length is taken from the anterior margins of the eyes to the apex of the elytra. The width of the rostrum is defined as the pterygial span (the distance between the outer margins of the pterygia). The concept of DUPORTE (1960) according to which the frons migrated to the top of the rostrum is not generally accepted, hence is not followed here. the eyes are taken to be the decisive morphological landmark, in accordance with the "frons-area between the eyes" as defined in Glossary of Weevil Characters (LYAL 2015). Epistomal setae denote setae along the outer margins of the lateral keels of the epistome. Statements concerning the relative length/width of various body parts result from the calculation of the two respective values: e.g. "elytra $1.5 \times$ longer than wide" is derived from $6 \mathrm{~mm}$ (length of elytra) / $4 \mathrm{~mm}$ (width of elytra). The genitalia of dissected specimens are stored in microvials with glycerine pinned under a card with the respective specimen.

Abbreviations used: BAHR - Friedhelm BAHR, Viersen, Germany; BAYE - Christoph BAYER, Berlin, Germany; BEHN - Lutz BEHNE, Seckenberg German Entomological Institute, Müncheberg, Germany; BIAL - Piotr Z. BIAŁookI, Sopot, Poland; CASA Roberto CASAlinI, Rome, Italy; COLO - Enzo Colonnelli, Rome, Italy; FREM - Jan FrEMUTH, Hradec Kralove, Czech Republic; HNHM - Hungarian Natural History Museum, Budapest, Hungary; PODL - Attila PodLussánY, Hungarian Natural History Museum, Budapest, Hungary; SDEI - Seckenberg German Entomological Institute, Müncheberg, Germany; WINK - Herbert WinKELMANN, Berlin, Germany.

\section{RESULTS}

Subfamily Entiminae

Tribe Otiorhynchini

Genus Otiorhynchus GERMAR, 1822

Subgenus Podonebistus ReITTER, 1912 (type species Otiorhynchus prolongatus STIERLIN, 1861)

Otiorhynchus (Podonebistus) trichopterus sp. $\mathbf{n}$.

(Figs 1, 2)

\section{Material examined}

Holotype female, dissected [left fore tarsus and left middle onychium missing]: Greece, Crete, Mt. Lefkas, Askifon/ 29-30.V.1993 leg. HeGYESsY G./ Otiorhynchus? new genus?, L. MAgnano det. [PODL]. Paratypes, males and females: GR, Kríti (Khaniá); around 


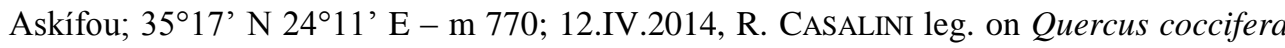
L., 21 exx. [18 CASA, 3 COLO] \Hellas: Kríti (Khaniá); Askífou - venetikó froúrio; N 35.17.56 E 24.11.32; 28.IV.2015 - E. ColonNelli \& G. MELONI legg. on Quercus coccifera L., 8 exx. [3 CASA, 5 COLO] \same locality, but 4.V.2015, 30 exx. partly preserved in acetone for further DNA analysis [6 BIAL, 3CASA, 21 COLO].

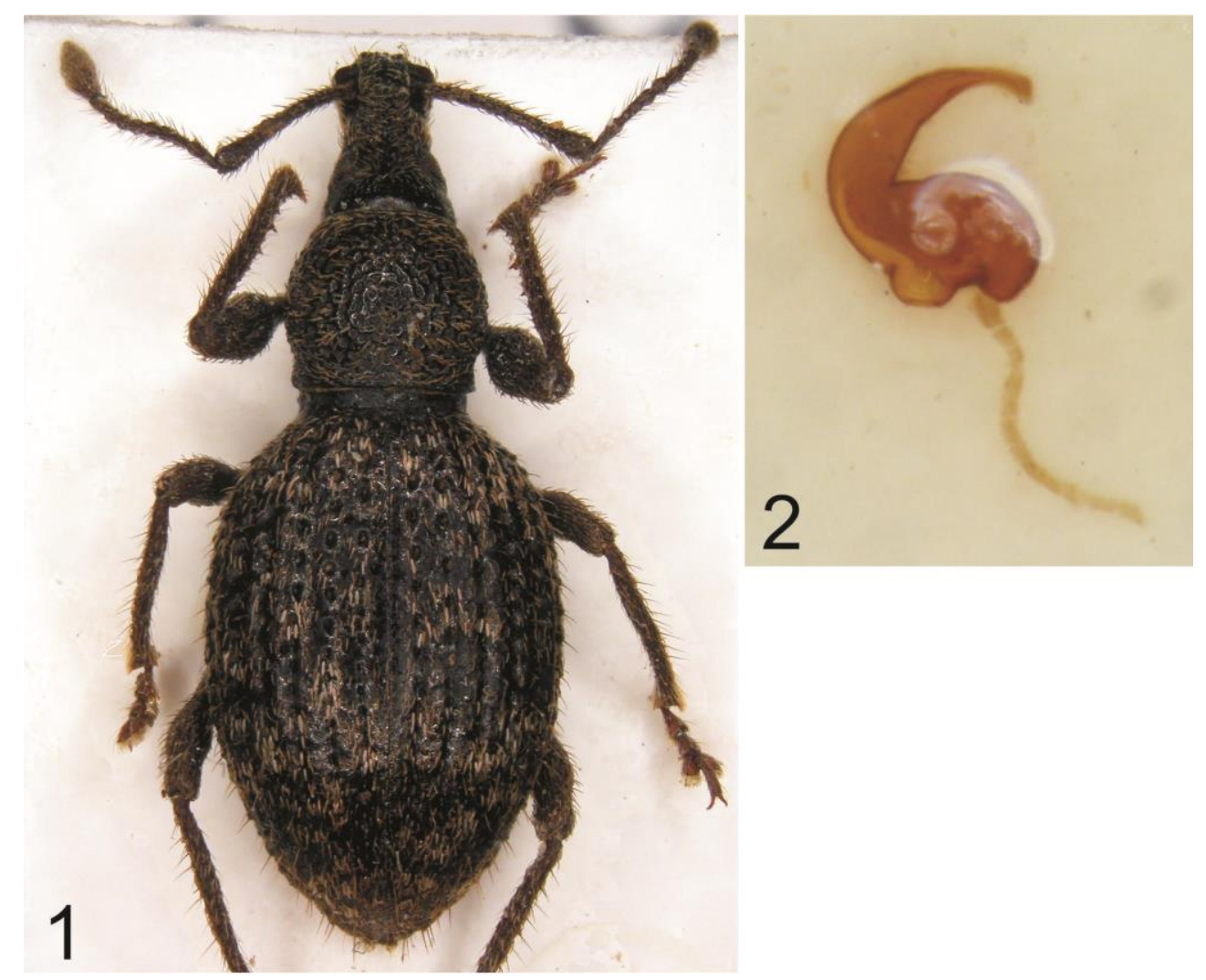

Figs 1-2. Otiorhynchus (Podonebistus) trichopterus: 1. habitus; 2. spermatheca.

\section{Diagnosis}

At first glance the new species (Fig. 1) differs from all other species of Podonebistus in the very long, subperpendicular setae on the elytra, prothorax, legs and antennae except for the tarsi and club; exceptionally slender antennae; all the femora are unarmed. O. nefandus FAUST, 1888 is similar to the new species in having indistinctly toothed femora, but it differs from $O$. trichopterus sp. n. (except for the lack of subperpendicular long setae) in 
the larger elytral strial punctures, and the much shorter antennal club with the first segment subspherical). Despite its strange appearance, O. trichopterus is nevertheless a typical representative of one of main lineages within Podonebistus, owing to other phylogenetically significant characters: structure of head with rostrum, feminine genitalia (the male of $O$. trichopterus remains unknown), pronotum, antennal club, $5^{\text {th }}$ ventrite, as well as the sculpture of the elytra and ventrites.

\section{Description (female)}

Body length 5.9-8.3 mm; entirely black; legs and antennae dark brown, tarsi and spines along ventral margins of tibiae much lighter in colour.

Head relatively narrow, at sides almost linearly tapered together with basal part of rostrum to hind margins of pterygia; covered with minute punctures, interstices with unclear microsculpture, shining; vestiture consists of recumbent, long, rather sparse, light brown hair-like scales directed to central point far behind frons fovea; frons fovea several times larger than surrounding punctation, deep, distinctly elongate, situated at midlength of interocular area; eyes situated clearly below frons level, moderately large, $1.25 \times$ narrower than frons, almost flat, slightly projecting; temples subequally long as longitudinal diameter of eye. Rostrum slightly elongate; pterygia weakly projecting, strongly distant from anterior margins of epistome; anterior part of dorsal wall (anteriad of antennal insertion) narrow, subparallelsided, somewhat divergent anteriad; epistome weakly expressed; hind part of dorsal wall (between frons and antennal insertions) weakly divergent backwardly, confluently separated from frons, covered with irregular, dense punctation, matt and with rather long, recumbent and weakly raised, brown-grey hair-like scales directed towards median keel and somewhat backwards; median keel well developed. Antennae exceptionally slender, all funicular segments strongly elongate; scape straight, covered with sparse, recumbent, narrow scales and with long, strongly semiprotruding setae, only apical portion thickened; club much broader than funicle, $2.25 \times$ longer than wide, as long as 3.5 distal funicular segments combined, sutures between segments well expressed, strongly asymmetrical. Prothorax small, $1.15 \times$ broader than long, much narrower than elytra, broadest at midlength, at sides weakly arcuate; disc covered with dense, coarse punctation, vestiture consists of recumbent, brown-grey, long, thin scales, and weakly raised, sparse, brown hairs; scales directed towards central point located somewhat behind centre of disc. Elytra almost $1.4 \times$ longer than wide; weakly expanded at shoulders, broadest at middle; base only slightly elevate; sides regularly arcuate, apical portion narrowly tapered; in lateral view weakly, regularly convex, apical declivity weakly convex, disc distinctly flattened; striae not impressed, punctures large, deep, funnel-like, with completely unclear margins, rather sparsely distributed; in apical portion punctures strikingly smaller, within well impressed furrows; interstices (in basal half of elytra) somewhat narrower than striae, 
somewhat uneven, covered with sparse, minute tubercles and with single row of long setae, longer than width of interstices, subperpendicular, slightly arcuate, interspaces subequally long as length of setae, moreover with recumbent, brown and grey scales variable in size arranged into irregular, sparse maculation; largest true scales rather broad, elongate oval; outer interstices instead of subperpendicular setae, with weakly elevated clearly arcuate, elongate scales.

Legs slender; all femora unarmed; tibiae covered with small, slightly raised, arcuate hairs and with setae subequally long as tibial width, subperpendicular on dorsal and lateral margins, interspaces somewhat shorter than length of setae; fore tibia straight, ventral margin with long, light-brown spines and short, semiprotruding hairs; mucro large; fore coxae clearly approaching anterior margin of prothorax; hind corbels with two small spurs; tarsi long, slender, second segment subisodiametric; onychium slender, its projecting portion about as long as third segment, distinctly longer in hind tarsi; claws large.

Ventral part of body sparsely covered with somewhat elevated hairs; ventrites 1 and 2 in males barely impressed on middle and a trifle more coarsely punctured that the quite flat ones of females, anal ventrite regularly rounded, $1.55 \times$ broader than long, covered with irregular in size, rather sparse puncturation and characteristic microsculpture, around entire margin slightly impressed.

Spermatheca (Fig. 2) with distinctly inflated corpus, small, broad ramus and minute, distinctly curved nodulus. Spiculum ventrale with wide, strongly sclerotized arms of margo basalis.

\section{Distribution}

The species is so far known exclusively from Crete and is most probably endemic to this island.

Subgenus Podonebistus ReITTER, 1912 (type species Otiorhynchus prolongatus STIERLIN, 1861)

\section{Diagnostic description}

All species here attributed to the newly erected subgenus are currently placed (Magnano \& Alonso-ZaraZaga, 2013) in the subgenus Podonebistus (type species Otiorhynchus prolongatus STIERLIN, 1861). However, the new subgenus differs from Podonebistus in the following characters (character states pertaining to Podonebistus in parentheses): dorsal wall of rostrum very narrow, strikingly, about $3 \times$ narrower than frons (Fig. 3), its anterior portion, distad of antennal insertions, strongly divergent anteriad (dorsal wall broad, only slightly narrower than frons, its anterior part only moderately divergent distad); hind part narrow, at antennal insertions ca $2.85 \times$ narrower than pterygial 
span, ca $1.65 \times$ than frons $(2.5 \times$ and $1.2 \times$ respectively, see Fig. 4 of $O$. jovis MILLER, 1862), clearly convex both transversally and longitudinally, with well-developed median keel, rather sharply separated from frons (flat, with unclear trace of median keel, weakly separated from frons); elytral apex not modified, Fig. 5 (apex of elytra extended into horizontal flat process strongly at angle to adjacent surface of elytra, Fig. 6); fore coxae subcentral, sternellum flat, invisible in lateral view (fore coxae strongly approximated to anterior margin of prothorax, sternellum large, strongly convex, well visible in side view); first ventral suture between first two ventrites well developed along its entire length (weakly developed in middle, superficial); fore femora, even though much bigger than remaining ones, not enlarged to such a degree as in Podonebistus, maximum height of femur much less than twice as broad as minimum width of femur between knee-lobe and swollen part of the femur (maximum height of fore femur much than $2 \times$ wider than minimum height of its distal portion); femora with minute, occasionally unclear teeth (tooth of fore femur usually well developed, predominantly complex); presence of minute tibial spurs (spurs not developed); antennae usually stouter, especially scape; median lobe of aedeagus (Figs. 7, 9) very slender, more than $4 \times$ longer than broad $(2.5-3.6 \times$; Figs. 8,10$)$, subequally long as apophyses, merely $2.8 \times$ wider than thick, top of apex in lateral view uniformly thin (distinctly swollen); transfer apparatus small, located far from basal part of projecting portion of endophallus, Fig. 7 (large, rather complex, situated at basal portion of projecting portion of endophallus, Fig. 5). Owing to the large number of phylogenetically relevant characters developed in different ways in the two groups, their status of distinct subgenera is beyond all doubt. Apart from morphological evidence, the two groups differ from each other in their type of distribution: Podonebistus can be considered a circumaegean lineage (mainly Greece and westernmost Asia Minor, whereas Podorhynchus comprises species distributed in the eastern part of the Black Sea basin.

\section{Etymology}

Derived from Podo-[nebistus], and suffix -rhynchus; gender masculine.

Otiorhynchus (Podorhynchus) cylindricus STIERLIN, 1877, new subgeneric placement

\section{Material examined}

Kaukas Leder/ coll. STIERLIN/ O. cylindricus STL [label with blue-grey frame]/ coll. DEI Eberswalde/ Syntypus [red museal label]/ Otiorhynchus cylindricus of STIERLIN Lectotypus Des. L. MAGNANo 1996 [SDEI]. 

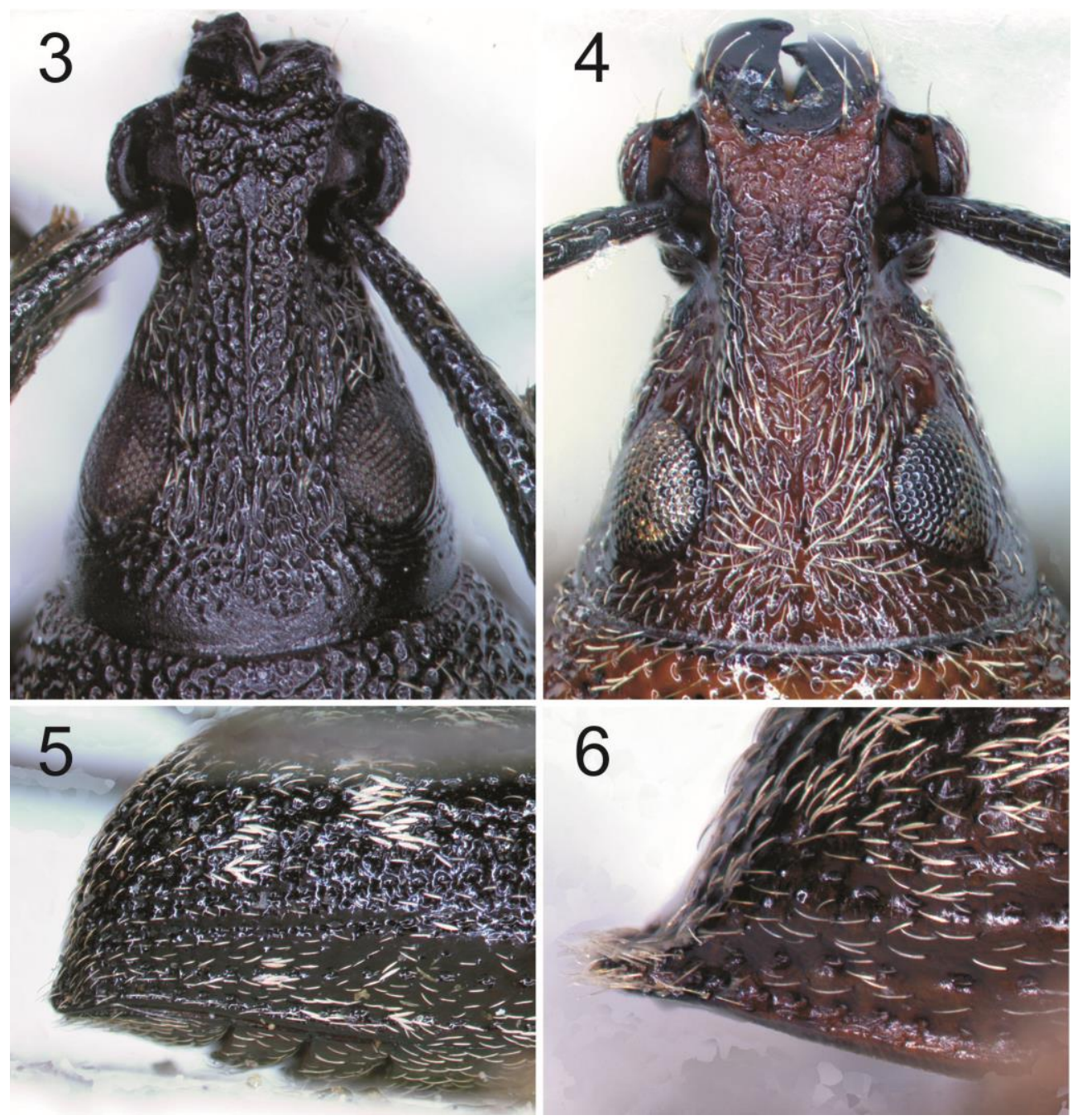

Figs 3-6. 3. Otiorhynchus (Podorhynchus) korotyaevi, head; 4. $O$. (P.) jovis, head; 5. $O$. (P.) korotyaevi, elytral apex lateral view; 6. $O$. (P.) jovis, elytral apex lateral view.

The holotype of $O$. cylindricus differs from $O$. korotyaevi (character states pertaining to this species in parentheses) in: antennal scape more slender; dorsal margin of fore tibia straight along its whole length (apical portion of dorsal margin clearly curved ventrad; median keel of rostrum lower, dorsal wall of rostrum less convex transversally, weaker at angle to frons; both head and rostrum less elongate; transfer apparatus situated in middle of distal half of aedeagal apophyses (slightly distad of apophyseal midlength). 


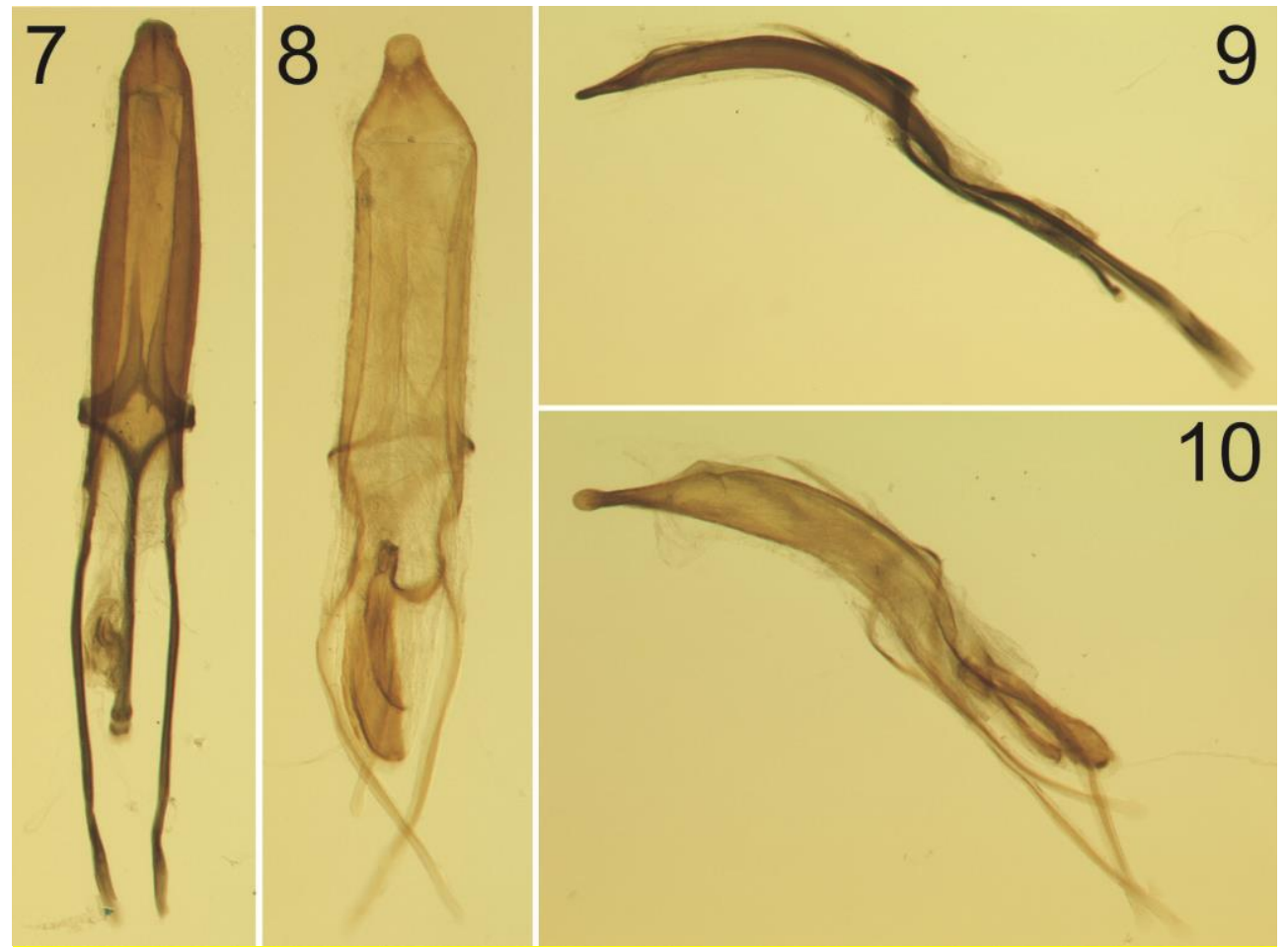

Figs 7-10. 7. Otiorhynchus (Podorhynchus) korotyaevi, aedeagus dorsal view; 8. O. (P.) jovis, aedeagus dorsal view; 9. O. (P.) korotyaevi, aedeagus lateral view; 10. $O$. (P.) aedeagus lateral view.

Otiorhynchus (Podorhynchus) korotyaevi DAVIDIAN \& GÜLTEKIN, 2006 new subgeneric placement

(Figs 3, 5, 7, 8)

\section{Material examined}

Kaukas; LeDER/ coll. ReITTER/ Paratypus 1877; Otiorhynchus cylindricus STIERLIN [museal label]; 1 ex.l as above, and with museal paratype label; 2 exx.l Caucasus; Meskisch. Gb.; LEDER. REITTER/ cylindricus STRL. coll. REITTER/Otiorhynchus cylindricus STIERL.; det. CSIKI, 1944; 1 ex.I Caucasus; Gelati/ coll. E. CsIKI; 1 ex.; [HNHM] Circassien Sotschi Carl Rost, 5 exx.। Abchasien Ca.[ucasus] Carl Rost, 3 exx. [NMP].

The determination of $O$. korotyaevi is based on the original description by DAVIDIAN \& GÜLTEKIN (2006). The authors compare the new species exclusively to Otiorhynchus 
prolongatus STIERLIN, 1861 and O. prolixus ROSENHAUER, 1847. They do not even mention $O$. cylindricus or any other species of the group of species known from the nearby Caucasus (O. korotyaevi has been described from north-eastern Turkey) although the similarity of $O$. korotyaevi to $O$. cylindricus can be inferred from the original descriptions even if they are devoid of the majority of phylogenetically significant characters. Although DAVIDIAN \& KESKIN (2010) correctly excluded O. cylindricus from Choilisanus (without indicating its proper position, however), the authors overlooked the fact that it had already been transferred from Choilisanus to Podonebistus by ARNOLDI (1972).

Subgenus Choilisanus REITTER, 1912 (type species Otiorhynchus balcanicus STIERLIN, 1861)

Otiorhynchus (Choilisanus) granicus sp. n.

(Figs 11, 12)

\section{Type material}

Holotype male, dissected: 08.05.2007 NW Turkey; Mt. 1294 m; NE Edremit; leg. P. BiaŁooki/ Choilisanus granicus sp. n.; holotype; des. P. BiAŁooKi 2008 [MNHW]. Paratypes: label as holotype, 49 exx. [BIAL].

\section{Diagnosis}

The new species (Fig. 11) differs from the great majority of congeners in its smaller body size; moreover, it differs from O. balcanicus STIERLIN, 1861, O. leuthneri SMRECZYŃSKI, 1977 and $O$. ege DAVIDIAN \& GÜLTEKIN, 2015 in the only indistinctly asymmetrical epistome; from O. megareoides SMRECZYŃSKI, 1977 in the more elongated elytra and the first funicular segment much longer than the second (in O. megareoides the first two funicular segments are subequally long). O. granicus sp. n. (Fig. 11) is very similar to O. idhaeus sp. n. (Fig. 13); for the differences between these species, see the diagnosis of the latter.

\section{Description (male)}

Body length 4.7-5.8 mm (holotype $4.7 \mathrm{~mm}$ ); entirely dark brown.

Head together with basal part of rostrum conically tapered; temple subequally long as eye diameter; frons fovea situated in hind portion of interocular area; eyes moderately big, $1.7 \times$ shorter than frons, somewhat elongate, distinctly convex, well impressed into head, not at all projecting, located well below frons level. 


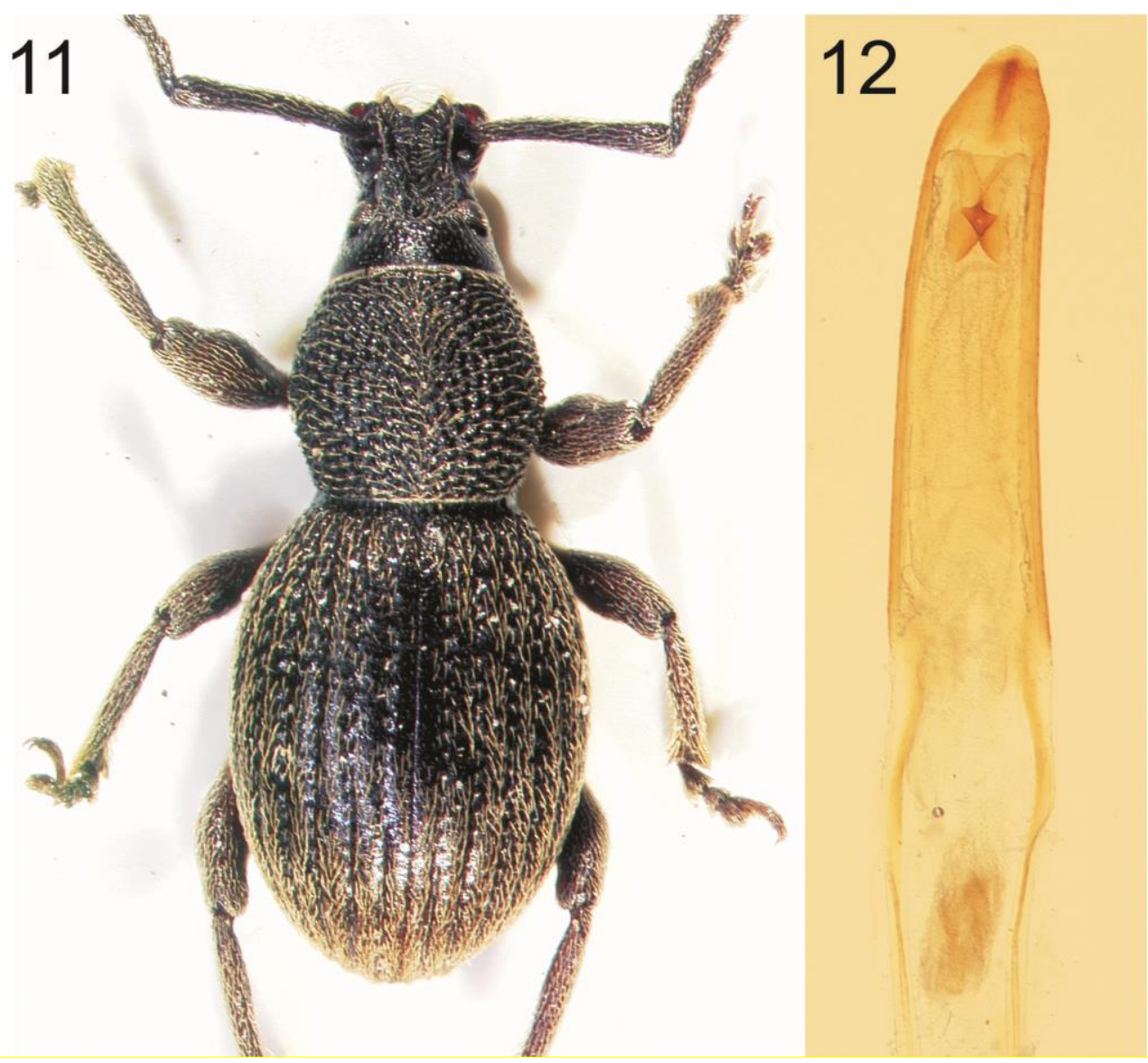

Figs 11, 12. 11. Otiorhynchus (Choilisanus) granicus sp. n., habitus; 12. O. (C.) granicus sp. n., aedeagus dorsal view.

Rostrum $1.25 \times$ broader than long; pterygia large, strongly projecting; scrobes large, its anterior margins slightly excised; hind part of dorsal wall (behind antennal insertion) of rostrum subparallelsided, covered with short, recumbent brown hair-like scales, median keel well developed; lateral margins sharply defined along anterior half, posteriorly well, but less sharply expressed; anterior part of rostrum dorsum rather strongly divergent anteriad, covered with dense, big punctation and sparse, brown, recumbent hair-like scales; epistome almost symmetrically triangular, strongly hollowed, lateral keels well developed, thin; the left keel clearly less convex, indistinctly more arcuately approaching margin of scrobes; epistomal setae complete (well developed along whole basal half of lateral keels of epistome), long. 
Antennae moderately slender, scape straight, weakly gradually expanding apicad; first funicular segment $3 \times$ longer than broad, almost cylindrical, $1.5 \times$ longer than next segment; second segment twice as long as broad; third segment slightly elongate; segments 4-6 isodiametric; last segment broader than remaining ones, rather weakly transverse; club elongate, $2.35 \times$ longer than wide, as long as 3 distal funicular segments combined, as wide as scape.

Prothorax slightly transverse; pronotum evenly rather weakly convex longitudinally, moderately transversally; at sides moderately, evenly arcuate, broadest in middle; disc covered with moderately dense tubercles well separated from each other, distinctly convex, somewhat flattened with rather big apical puncture; latero-ventral portions covered with much less convex, bigger tubercles.

Elytra $1.3 \times$ longer than wide, moderately arcuate, broadest slightly in front of midlength, apical part rather narrowly rounded; in lateral view weakly, evenly convex; apical declivity weakly convex, only close to apex perpendicular; interstices flat, $1.5 \times$ broader than striae, covered with irregular microrugosity (outer interstices with weakly convex tubercles), shining, and with light-brown, rather sparse, recumbent or indistinctly elevated, arcuate hair-like scales. Legs. Femora unarmed, covered with recumbent, moderately dense grey hairs; tibiae with minute mucro obscured by apical tuft of hairs; hind tibiae with two spurs; tarsi small, second joint subtriangular, subisodiametric.

Ventral portion of the body with moderately coarse, rather dense puncturation and with moderately dense, semierect hair-like scales; terminal ventrite flat, slightly convex basally, twice as broad as long.

Females differ indistinctly from males in slightly larger body; elytra somewhat broader, stronger expanded at shoulders, more broadly rounded at apex; first two ventrites not impressed; tarsi indistinctly more slender.

\section{Ecology}

All specimens were sifted at ca $1200 \mathrm{~m}$ amsl from ground litter under undetermined species of Astragalus LinNAEUS, 1753.

\section{Etymology}

The name (noun in apposition) is derived from the ancient River Granicus (today the Biga Çayı) in north-western Turkey, not far from ancient Troy, the site of the Battle of the River Granicus in May 334 BC between Alexander the Great and the Persian Empire. 


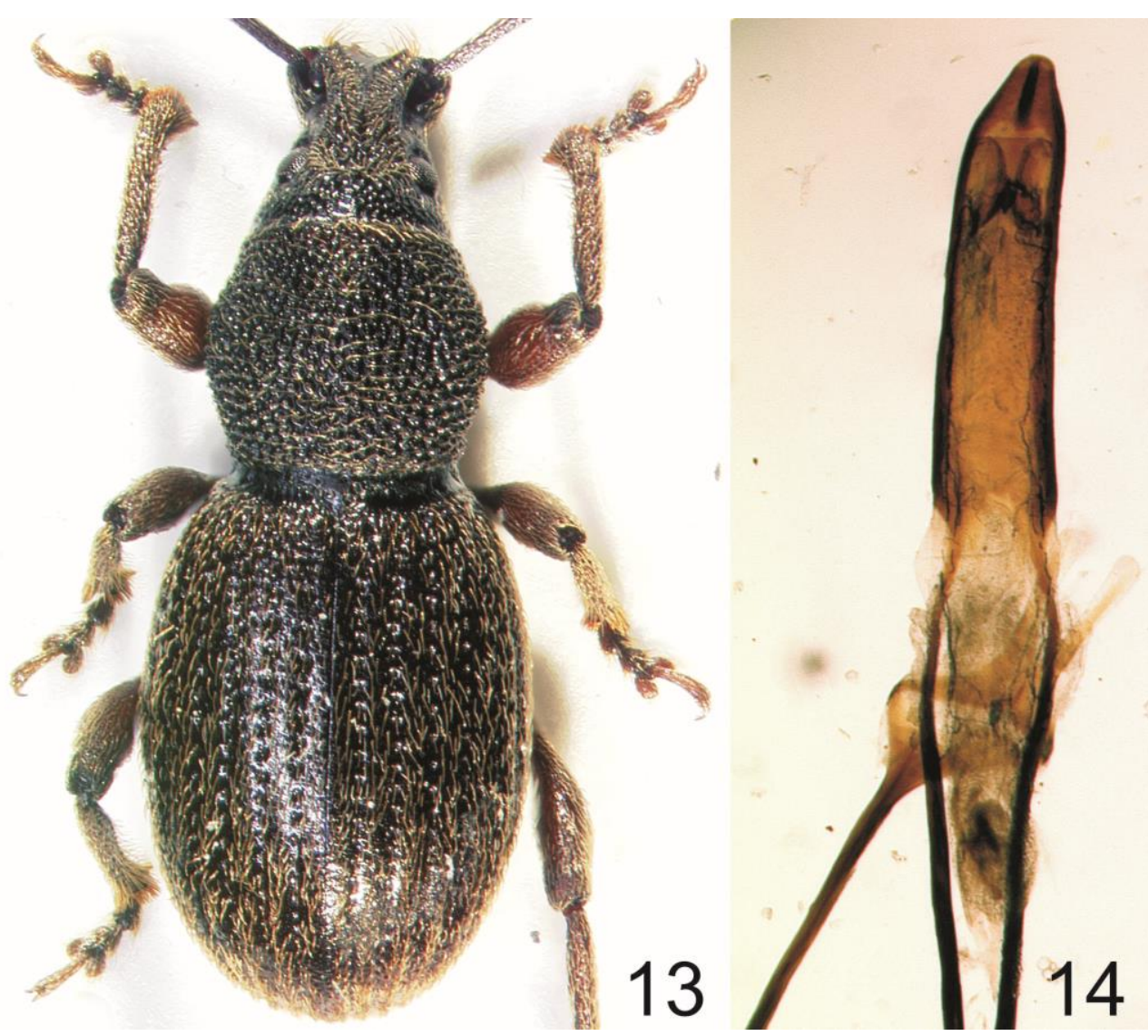

Figs 13, 14. 13. Otiorhynchus (Choilisanus) idhaeus sp. n., habitus; 14. O. (C.) idhaeus sp. n., aedeagus dorsal view.

Otiorhynchus (Choilisanus) idhaeus sp. n.

(Figs 13, 14)

\section{Type material}

Holotype male, dissected: Gr.: Crete Oros Idi, Nida plt. 1400 m; 15.5 .2006 (FO5); leg. Ch. BAYER [DEI]. Paratypes: as ht, 47 exx.। Crete Oros Idi; Nida-Hochebene, $1360 \mathrm{~m} ; 35^{\circ}$ 12' 23” N 24 50' 08” E; 6.10.2006 leg. BAHR, BAYER \& BRUNNER (FO6), 9 exx. [BAHR; BAYE; XB; BIAL] $\backslash$ GR: Kreta, Nida-Plateau NE, 1477 m; 35'13'08” N 24 52' 32” E; 07.-23.05.2008 FO5); leg. BAHR, BAYER \& BRUNNER / unter den Polstern von Astracantha cretica und Cichorium spinosum, 72 exx. [BAHR, BAYE, WINK] Greece: Crete; prov. Rethymno; Mts. Ida, 1300 m/ Ideon Andron; 1993.V.12.; leg. ROZNER I./ Otiorhynchus 
athosiensis Dan.; det. A. Podlussány/ Coll. Podlussány A., 3 exx. [PODL].ı Crete, 10.6.1981; Ida Ori Mts.; Nida, Sv.BILY leg., 2 exx. [FREM].

\section{Diagnostic description}

The new species (Fig. 13) is very similar to Otiorhynchus granicus sp. n. (character states pertinent to this species in parentheses) and differs from it in the following rather subtle characters: shorter, stouter rostrum; anterior part of rostrum dorsum more strongly divergent; hind part of rostrum dorsum distinctly convex longitudinally, with lateral margins well expressed, in the form of sharp, keel-like edges strongly converging towards frons (hind part of rostrum dorsum flat, lateral margins less developed, subparallel to each other); anterior margins of pterygia distinctly oblique to longitudinal body axis (nearly perpendicular); pronotum slightly broader, $1.35 \mathrm{x}$ narrower than elytra $(1.4 \times)$; pronotal tubercles smaller, more flattened, denser; elytra less arcuate at sides, apical portion broader, rounded, in lateral view less regularly convex; hind tibiae with single spur; suture between first and second ventrite much less pronounced, in its middle portion in the form of thin, superficial line.

Aedeagus (Fig. 14) less tapered apicad: basal width $1.25 \times$ broader than subapical portion $(1.4 \times)$; endophallic structures show minute, practically indescribable differences owing to their vagueness (compare Figs. 7 and 9).

\section{Etymology}

The name is derived from the Idha Mountain in central Crete.

List of proposed taxonomic actions

Otiorhynchus (Podonebistus) trichopterus sp. n.

Otiorhynchus (Choilisanus) granicus sp. n.

Otiorhynchus (Choilisanus) idhaeus sp. n.

Otiorhynchus (Podorhynchus) subgen. n. (type species O. cylindricus STIERLIN, 1877)

Otiorhynchus (Podorhynchus) cylindricus (STIERLIN, 1877) new subgeneric placement [from Otiorhynchus (Podonebistus)]

Otiorhynchus (Podorhynchus) fortiscapus (ARNOLDI, 1972) new subgeneric placement [from Otiorhynchus (Podonebistus)]

Otiorhynchus (Podorhynchus) glolae (ARNOLDI, 1972) new subgeneric placement [from Otiorhynchus (Podonebistus)]

Otiorhynchus (Podorhynchus) korotyaevi (DAVIDIAN \& GÜLTEKIN, 2006) new subgeneric placement [from Otiorhynchus (Podonebistus)]

Otiorhynchus (Podorhynchus) ritsae (ARNOLDI, 1972) new subgeneric placement [from Otiorhynchus (Podonebistus)] 


\section{ACKNOWLEDGEMENTS}

I would like to express my sincere thanks to Lutz BEHNE, Senckenberg German Entomological Institute, Müncheberg, Germany for the loan of the material and for help in finding literature, and also to Otto MERKL, Gyözö SzÉL and Attila PODLUSSÁNY, all from the Hungarian Natural History Museum in Budapest, Hungary, for their permission to study the museum's collection (or A. PODLUSSÁNY's private one), for their kind help during my visits to the museum, and for loans of material; to Roberto CASALINI and Enzo COLONNELLI, Rome, Italy for presenting me with paratypes of one of the new species here described. Thanks are also due to Marek WANAT, Natural History Museum of Wrocław University, Wrocław, Poland for the opportunity to take photographs. The constructive criticisms on the part of the two anonymous reviewers is also acknowledged.

\section{REFERENCES}

ARNOLDI L.V. 1972. New species of genus Otiorhynchus GERM. (Coleoptera, Curculionidae) from the Caucasus. Entomologicheskoe Obozrenie, 51(1): 127-132. (in Russian)

DAvidian G.E., GüLteKIN L. 2006. Contribution to the knowledge of the weevil genus Otiorhynchus (Coleoptera, Curculionidae) from northeastern Turkey and Transcaucasia. Zoologicheskii Zhurnal 85(4): 479-492. (in Russian)

Davidian G.E., Gültekin L. 2015. Contribution to the knowledge of the weevil subgenus Choilisanus ReITter, 1912, genus Otiorhynchus Germar, 1822 (Coleoptera: Curculionidae: Entiminae). Journal of Insect Biodiversity 3(4): 1-13.

Davidian G.E., Keskin B. 2010. To the knowledge of the weevil genus Otiorhynchus GeRMAR, 1824, subgenus Choilisanus ReITTER, 1912 (Coleoptera: Curculionidae). Russian Entomological Journal 19(1): 61-65.

DaVidian G.E., SAVITSKy V.Yu. 2006. Review of the weevil subgenera Namertanus ReITTER and Troglonamertanus subgen. n., genus Otiorhynchus GERMAR (Coleoptera: Curculionidae), from the Caucasus. Trudy Russkogo Entomologicheskogo Obshchestva 77(1): 48-84. (in Russian)

DuPoRTE E.M. 1960. Evolution of cranial structures in adult Coleoptera. Canadian Journal of Zoology 38(3): 655-675.

GERMAR E. 1822. Fauna Insectorum Europae. Fasciculus septimus. Kummelius, Halle.

LyAl C.H.C. (ed.) 2015. Glossary of Weevil Characters. International Weevil Community Website. Intrnet: http://weevil.info/glossary-weevil-characters (accessed 12.05.2015).

Magnano L. 1998. Notes on the Otiorhynchus GERmar, 1824 complex (Coleoptera: Curculionidae). [in]: E. Colonnelli, S. Louw, G. Osella (eds). Taxonomy, ecology and distribution of Curculionoidea (Coleoptera: Polyphaga). Proceeding of a Symposium (22 August, 1996, Florence, Italy). XX International Congress of Entomology. Museo Regionale di Scienze Naturali, Torino, 51-80. 
Magnano L., Alonso-Zarazaga M.A. 2013. Otiorhynhini. [in:] I. Löbl, A. Smetana (eds). Catalogue of Palaearctic Coleoptera. Vol. 8. Curculionoidea II. Brill, Leiden, 302-347.

STIERLIN G. 1861. Revision der europäischen Otiorhynchus-Arten. Berliner Entomologische Zeitschrift 5(Beiheft): 1-344.

RosEnHAUER W.G. 1847. Beiträge zur Insekten-Fauna Europas, Erstes Bändchen; enthält die Beschreibung von sechzig Käfern aus Bayern, Tyrol, Ungarn etc., sowie Käfer Tyrols, nach den Ergebnissen von vier Reisen zusammengestellt. Theodor Blaesing, Erlangen.

Received: 16 April 2015

Accepted: 10 May 2015 